\title{
Assessing the trophic status of Lake Mikri Prespa, Greece
}

\author{
T.S. Koussouris ${ }^{1}$ \\ A.C. Diapoulis 1 \\ E.T. Balopoulos 1
}

Keywords: Trophic status, modelling, lake, Greece.

Lake Mikri Prespa is a shallow water basin characterized by unstable thermal stratification, primary dimictic conditions and clinograde distribution of dissolved oxygen.

The nutrient concentrations are high, indicating a trend towards eutrophication. Total phosphorus input calculated on the basis of the export coefficient accounting for land-uses and other sources is estimated to be of the order of $15 \times 10^{6}$ $\mathrm{kg} \mathrm{yr}^{-1}$. A mathematical model is applied to assess the trophic status of Lake Mikri Prespa in the light of development projects recently undertaken in its catchment area. Evaluation of the trophic status reveals that the critical and permissible loading for Lake Mikri Prespa are 0.07 and $0.03 \mathrm{gm}^{-2} \mathrm{y}^{-1}$, respectively. Present loading of the lake is estimated at 0.27 $\mathrm{gm}^{2} \mathrm{y}^{-1}$ indicating that the lake is already at a dangerous level. On the basis of the employed O.E.C.D. relationships, Lake Mikri Prespa is presently classitied as mesotrophic to eutrophic.

Evaluation de l'étal trophique du Lac Mikri Prespa (Grèce)

Mots clés : Etat trophique, modélisation, lac, Grèce.

Le lac Mikri Prespa est un bassin dimictique peu profond caractérisé par une stratification thermique instable et une distribution clinograde d'oxygène.

Les fortes teneurs en nutriments indiquent une tendance à l'eutrophisation.

L'apport du Phosphore total calculé à partir de coefficients d'export prenant en compte l'utilisation des terres et autres sources est de l'ordre de $15 \times 10^{6} \mathrm{~kg}^{\circ} \mathrm{an}^{1}$

Un modèle mathématique, utilisé pour évaluer la réponse du lac Mikri Prespa aux projets d'aménagement entrepris dans son bassin versant, permiet d'estimer les charges critiques et tolérables respectivement à 0,07 et 0,03 gm ${ }^{2} \mathrm{y}^{-1}$ de $\mathbf{P}$ total. La charge actuelle estimée à $0.27 \mathrm{gm}^{-2} \mathrm{y}^{-1}$ indique que le lac se situe déjà à un niveau dangereux. Sur la base des normes O.C.D.E., le lac Mikri Prespa est actuellement classé dans les catégories mésotrophe à euirophe.

\section{Introduction}

During the last decades various development projects, mainly intensified agricultural practices, have not only threatened the natural environment but also altered directly or indirectly the trophic situation of Lake Mikri Prespa (Koussouris \& Diapoulis 1983. Newbold 1986). This lake is considered to be an internationally important wetland offering valuable sites for waterfowl, where rare and threatened species such as pelicans, cormorants, egrets, herons etc. occur (e.g. Terrasse et al. 1969, Pyrovetsi et al.

\footnotetext{
1. National Centre for Marine Research, GR-16604, Athens, Greece
}

1984, Katsadorakis 1986). The ecologically diversified fauna and flora, as well as the luxuriant aquatic vegetation, the extensive marshes, the floating islets of thick reed clusters, the wet meadows and the lake itself make Lake Mikri Prespa a rich wildlife area.

Recent limnological investigations carried out by the National Centre for Marine Research, Department of Inland Waters have provided information on the morphological characteristics of the lake and its nutrient conditions (Tables I, II).

This article deals with a hydrobiological analysis of the lake, an estimation of nutrient loading and finally with the application of a mathematical model for the evaluation of its trophic status on the basis of an analysis of the total phosphorus input. 
Table I. Main morphometrical features of Lake Mikri Prespa.

\begin{tabular}{lrlr}
\hline Lake surface area $\left(\mathrm{km}^{2}\right)$ & 53 & Shoreline length $(\mathrm{m})$ & 58 \\
Total watershed $\operatorname{rrea}^{\left(\mathrm{km}^{2}\right)}$ & 260 & Development of shoreline & 2.3 \\
Lake volume $\left(\times 10^{6} \mathrm{~m}^{3}\right)$ & 221 & Relative depth (\%) & 1.02 \\
Maximum depth $(\mathrm{m})$ & 8.4 & Development of volume & 0.48 \\
Mean depth $(\mathrm{m})$ & 4.1 & Coverage of aquatic vegetation & 13 \\
Maximum length $(\mathrm{km})$ & 13.6 & $\left(\mathrm{~km}^{2}\right)$ & 40 \\
Maximum width $(\mathrm{km})$ & 6.7 & Open lake water $\left(\mathrm{km}^{2}\right)$ & 1 \\
Mean width $(\mathrm{km})$ & 3.8 & Area of islands $\left(\mathrm{km}^{2}\right)$ & \\
\hline
\end{tabular}

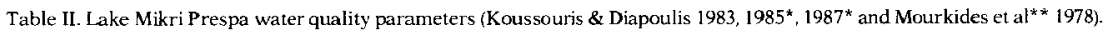

\begin{tabular}{|c|c|c|c|c|}
\hline Parameters & Units & Mean & Minimum & Maximum \\
\hline Secchi disc depth & m & 1.65 & 0.85 & 3.0 \\
\hline Dissolved oxygen & $\mathrm{mg} \cdot \mathrm{I}^{-1}$ & 8.2 & 0.1 & 13.5 \\
\hline $\mathrm{pH}$ & & 8.1 & 6.9 & 8.6 \\
\hline Alkalinity total & meql-1 & 2.7 & 1.7 & 3.0 \\
\hline Conductivity & ${ }_{\mu}$ Mos. $\mathrm{cm}^{-1}$ & 175 & 60 & 256 \\
\hline Chloride & mg. $1^{-1}$ & 6.7 & 4.0 & 10.0 \\
\hline Hardness total & mg. $1^{-1} \cdot \mathrm{CaCO}_{3}$ & 134 & 85 & 164 \\
\hline Hardness calcium & $\mathrm{mg} \cdot 1^{-1} \cdot \mathrm{CaCO}_{3}$ & 88 & 60 & 105 \\
\hline $\mathrm{BOD}_{5}{ }^{* \pi}$ & $\mathrm{mg} \cdot 1^{-1}$ & 2.7 & & \\
\hline P.PO ${ }^{-3 *}$ & $\mu \mathrm{g} \cdot \mathrm{1}^{-1}$ & 10.4 & 2.8 & 22.0 \\
\hline $\mathrm{N} . \mathrm{NO}_{3}^{+}{ }^{*}$ & $\mu \mathrm{g} \cdot 1^{-1}$ & 61.2 & 0.3 & 337.4 \\
\hline N.NO${ }^{-}{ }^{-}$ & $\mu \mathrm{g} \cdot \mathrm{I}^{1} \cdot 1$ & 1.9 & 0.6 & 6.2 \\
\hline N.NH ${ }^{+*}$ & $\mu \mathrm{g} .1^{-1}$ & 48.4 & 9.4 & 168.0 \\
\hline Total Phosphorus ${ }^{*}$ & g. 1.1 & 280 & 9.0 & 42.0 \\
\hline Chlorophyll -a."*** & $\mathrm{mg} \cdot \mathrm{m}^{-3}$ & 6.1 & 4.4 & 11.7 \\
\hline $\mathrm{N}: \mathrm{P}$ & & 16.1 & 3.2 & 41.1 \\
\hline
\end{tabular}

*, unpublished data during March 1985 and April, June 1987.

\section{Description of the area}

Lake Mikri Prespa lies on the Greek-Albanian border in Macedonia, Greece $\left(40^{\circ} 45-\mathrm{N}-21^{\circ} 06-\mathrm{E}\right)$ at 853.5 m. above sea level, has a surface of $53 \mathrm{~km}^{2}$, a maximum depth of $8.4 \mathrm{~m}$. and a mean depth of $4.1 \mathrm{~m}$. The lacustrine system is within a small catchment area of $207 \mathrm{~km}^{2}$, consisting geologically of carbonate rock $(63 \%)$, quaternary formations (19\%), igneous rock (12\%) and metamorphic rock (6\%) (I.G.M.E. 1983). (Fig. 1).

The lake is supplied with water only seasonally through surface runoff from a number of small creeks, torrents and from irrigation and also probably through seepage and underground sources.
The lake has a natural outflow to lake Megali Prespa, as well as into fissures in the underground.

The usage of the lake water is mainly for irrigation $\left(8.5 \times 10^{6} \mathrm{~m}^{3} \mathrm{y}^{-1}\right)$ with increasing demands each year, for $17.4 \mathrm{~km}^{2}$ of intensity cultivated land. The lake is also used for commercial fishery. Especially the fish catches and their species composition have reduced dramatically during the last two decades from 450 tons in 1964 to 50 tons in 1983 (Koussouris \& Diapoulis 1983).

The watershed area is mostly covered by deciduous oak and beech forest $(72.4 \%)$ with increasing timber-felling activities. The rest of the land is mainly used for pasturing (18.2\%) and agriculture $(8.4 \%)$, from which $7.5 \mathrm{~km}^{2}$ is irrigated with lake 


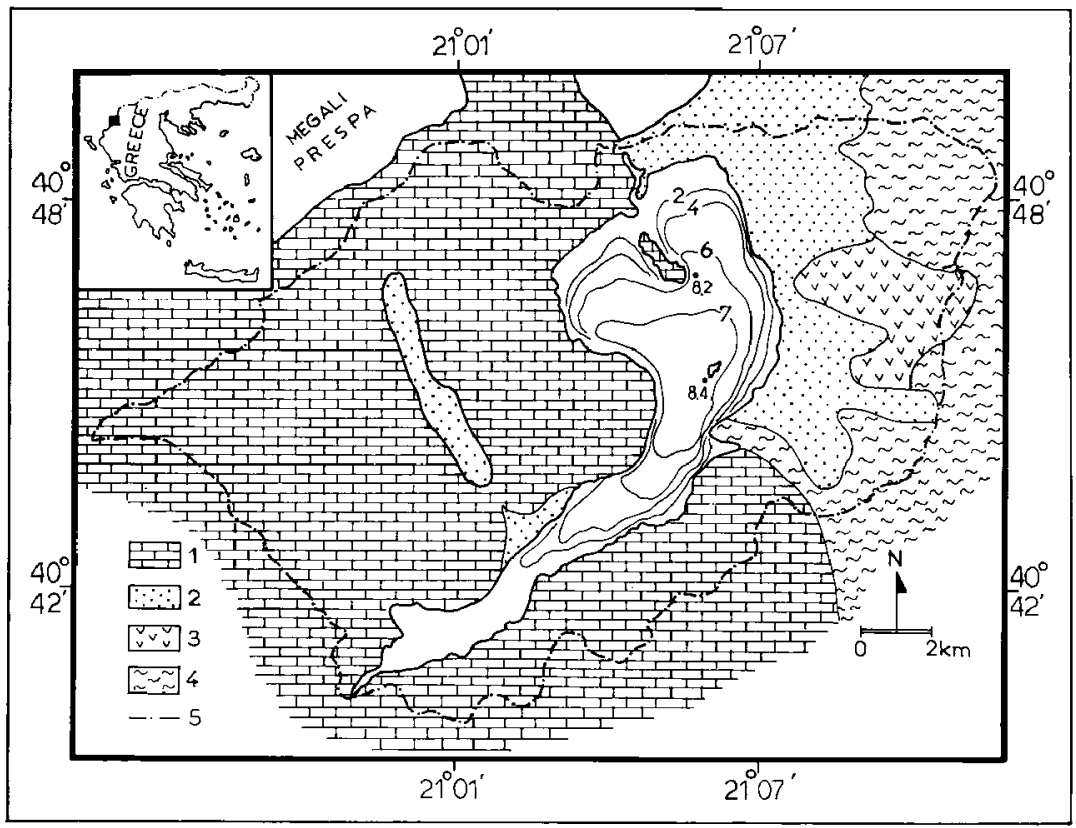

Fig. 1. Bathymetric contours of the Mikri Prespa lake and the geological profile of its catchment area. 1 ( $=$ Carbonate rocks, 2 = Quaternary formations, $3=$ Metamorphic rocks, $4=$ Igneous rocks, $5=$ Catchment area).

water, while almost $1 \%$ is housing areas with 2000 habitants.

The most pronounced features of the lake environment are :

- the extensive reed belt surrounding the lakeshore :

- the organic matter produced mainly by reeds that contributes to the nutrient loading of the lake ;

- the agricultural runoff and the increasing soil erosion that accelerate the trophic conditions of the lake :

- the richness and importance of its avifauna.
According to data from the National Meteorological Service (1965-1985) the climatic regime of the area could be characterized as semihumid to humid with mesothermal conditions. Mean annual air temperature (average of 20 years) is $11.3^{\circ} \mathrm{C}$ (range $1.4 \cdot 21.6^{\circ} \mathrm{C}$ ). The mean annual precipitation is $610 \mathrm{~mm}$. on the lake and $667 \mathrm{~mm}$. on the watershed (Fig. 2). The remaining meteorological parameters, in annual mean values are:

- evaporation, $681 \mathrm{~mm}$;

- evapotranspiration, $457 \mathrm{~mm}$;

- potential evapotranspiration, $689 \mathrm{~mm}$;

- relative humidity, $63.4 \%$;

- main wind direction, N-W. 


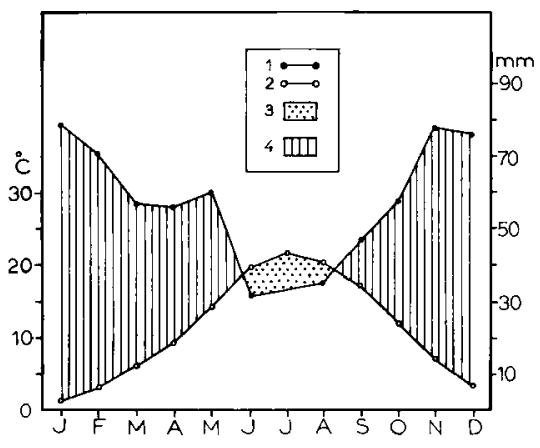

Fig. 2. Height of precipitation (1) and mean air temperature (2) of the study area. $(3=$ Arid period, $4=$ Humid period).

\section{Hydrological analysis}

To evaluate the present level of the trophic status of Lake Mikri Prespa the annual hydrological budget has been established. Morphometry, climate and nutrient loading do not vary significantly from year to year. Therefore, it may be assumed that the water budget of the lake is in a steady state. The simplified annual hydrological balance of the lake can be adequately described by Ward's (1975) formula :

$P_{L}+R+G_{L}=E_{a}+Q+I R(1)$

where:

$\mathbf{P}_{\mathrm{L}}=$ the precipitation volume on the lake.

$\mathbf{R}=$ lateral flow and surface runoff,

$\mathbf{G}_{\mathrm{L}}=$ total underground inflow to the lake,

$\mathbf{E}_{\mathrm{a}}=$ evaporation volume of the lake,

IR = the irrigation water volume from the lake,

$Q=$ the surface outflow from the lake plus the underground seepages from the lake.

According to Ward's (1975) analysis, $R$ and $\mathbf{G}_{\mathbf{L}}$ depend on climatic and physiographic parameters, of which geological structure of the rocks constitutes the decisive factors of the watershed area. However, $R$ and $G_{L}$. may also be calculated by the following formulae :

$$
\begin{aligned}
\mathrm{R} & =\mathrm{c} \times \mathrm{A}_{\mathrm{t}} \times \mathrm{P}_{\mathrm{t}}(2) \\
& =0.20 \times 207 \times 667=27.6 \times 10^{6} \mathrm{~m}^{3} \\
\mathrm{G}_{\mathrm{L}} & =\mathrm{C}_{\mathrm{I}} \times A_{\mathrm{t}} \times \mathrm{P}_{\mathrm{t}}(3) \\
& =0.36 \times 207 \times 667=49.7 \times 10^{6} \mathrm{~m}^{3}
\end{aligned}
$$

where :

$c=$ the actual runoff coefficient $(\sim 0.20)$

$A_{t}=$ the terrestrial area

$\mathbf{P}_{\mathbf{t}}=$ the precipitation on the terrestrial area

$\mathrm{C}_{\mathrm{I}}=$ the total infiltration coefficient of the area (see Table III)

(74.75/207 $=0.36$ ).

The remaining terms of equation (1) may be estimated from the following:

$$
\begin{aligned}
\mathrm{P}_{\mathrm{L}} & =A_{\mathrm{L}} \times \mathrm{P}_{\mathrm{r}}(4) \\
& =53 \times 610=32.3 \times 10^{6} \mathrm{~m}^{3} \\
\mathrm{E}_{\mathrm{a}} & =A_{\mathrm{L}} \times \mathrm{E}_{\mathrm{r}}(5) \\
& =53 \times 681=36.1 \times 10^{6} \mathrm{~m}^{3} \\
\mathrm{IR} & =\mathrm{IR}_{\mathrm{a}} \times A_{\mathrm{v}}(6) \\
& =7.5 \times 1.13=8.5 \times 10^{6} \mathrm{~m}^{3}
\end{aligned}
$$

where :

$A_{L}=$ lake's area

$I_{\mathrm{a}}=$ irrigated area

$A_{v}=$ the abstracted water volume

$P_{r}=$ precipitation on the watershed

$\mathbf{E}_{\mathbf{r}}=$ evaporation rate

Substituting the numerical values of $c, A_{T}, P_{t}, P_{r}, A_{L}, A_{V}, C_{I}, E_{r}, I R_{a}$ from Tables $I$ and II and subsequently $R, G_{L}, P_{L}, E_{a}$, and IR in Equation (1) results that the total outflow from the lake is:

$\mathrm{Q}=65 \times 10^{6} \cdot \mathrm{m} \cdot{ }^{3}(7)$

Then, other hydrological parameters, like the areal water load (hydraulic load) (8), the hydraulic retension time (residence time) (9) and the renewal time (10) may be estimated by the following formulae, substituting the total outflow from the lake (Q) and total inflows to the lake $\left(I_{n}=R+G_{l}\right)$ from equation (7) and formula (1), while and $V$ and $A_{L}$ from Table I :

$$
\begin{aligned}
\mathrm{sq} & =\mathrm{Q} / \mathrm{Al}(8) \\
& =65 / 53=1.2 \mathrm{~m} \mathrm{y}^{-1} \\
\mathrm{t} & =\mathrm{V} / \mathrm{Q}(9) \\
& =221 / 65=3.4 \text { years } \\
\mathrm{r} & =\mathrm{V} / \mathrm{In}(10) \\
& =221 / 109.6=2.0 \text { years }
\end{aligned}
$$

where :

$\mathrm{V}=$ lake volume

$\mathbf{I}_{\Omega}=$ inflow into the lake 
Table III. Infiltration coefficient factor on the geological formations of the catchment area in Mikri Prespa according to survey on greek soils (Soulios 1978, Papakonstantinou 1979).

\begin{tabular}{|c|c|c|c|}
\hline $\begin{array}{l}\text { Geological } \\
\text { Formations }\end{array}$ & $\begin{array}{c}A_{t} \\
k^{2}\end{array}$ & C. & $\begin{array}{l}\mathrm{A}_{1} \times \mathrm{C}_{\mathrm{P}} \\
\mathrm{km}^{2}\end{array}$ \\
\hline \multicolumn{4}{|l|}{ Carbonate } \\
\hline \multicolumn{3}{|l|}{ Metamorphic } & 0.87 \\
\hline \multicolumn{3}{|l|}{ Igneous } & 1.74 \\
\hline \multicolumn{4}{|l|}{$\begin{array}{l}\text { Quaternary } \\
\text { formations }\end{array}$} \\
\hline $\begin{array}{l}\text { - agricultural land } \\
\text { - irrigated land } \\
\text { - other formation }\end{array}$ & $\begin{array}{c}10.0 \\
7.4 \\
21.9\end{array}$ & $\begin{array}{l}0.18 \\
0.25 \\
0.15\end{array}$ & $\begin{array}{l}1.80 \\
1.85 \\
3.29\end{array}$ \\
\hline Total & 207,0 & & 74.75 \\
\hline \multicolumn{4}{|c|}{ Total infiltration Coefficient of the Area, $C_{1}=A_{t} \times C_{p} / A_{t}=0.36$} \\
\hline
\end{tabular}

Key: $A_{t}=$ Area terrestrial

$C_{p}=$ Partial infiltration coefficient on a formation

$C_{I}=$ Total infiltration coefficient of the area

\section{Trophic situations-nutrient loadings}

Lake Mikri Prespa, because of its shallowness has an unstable thermal stratification, although dimictic situations primarily occur every 2-3 years, when ice covers the lake for a few weeks. In calm sum. mer conditions the unstable thermocline starts from $1.0 \mathrm{~m}$. depth and reaches $4.5 \mathrm{~m}$.

The water temperatures ranges (Koussouris \& Diapoulis 1983) between :

8.8-11.1 ${ }^{\circ} \mathrm{C}$ during the spring;

18.3-28.1 $1^{\circ} \mathrm{C}$ during the summer :

$18.7-22.5^{\circ} \mathrm{C}$ during the fall :

$4.0-12.4^{\circ} \mathrm{C}$ during the winter.

The various water quality variables are given in Table II with their averages and ranges. The lake water is moderately hard and turbid with buffering capacity (between $1.7 \cdot 3.0$ meq $\mathrm{l}^{-1}$ ) and is well oxygenated, except a layer near to bottom during short periods and in a few sites ( $0.1-4.8$ p.p.m.). Ammo. nia does not remain bellow the $20 \mu \mathrm{g} \mathrm{l}-1 \mathrm{~N} . \mathrm{NH}_{4}+$ standard, while nitrate may exceed the $60 \mu \mathrm{g} \mathrm{l-1}$ N. $\mathrm{NO}_{3}-$. Nitrites range from 0.6-6.2 $\mu \mathrm{g} \mathrm{l}^{-1}$, phosphates from 2.8-22.0 $\mu \mathrm{g} \mathrm{l}^{-1}$ and total phosphorus from $9.042 .0 \mu \mathrm{g} \mathrm{l}^{-1}$.
For the evaluation of the trophic status in Lake Mikri Prespa it is useful to compare values of Table II, that contains published and unpublished data, with Wetzel's (1983) suggestion that the N/P ratio for optimal algal growth is $7 / 1$ by weight. The fact that in Lake Mikri Prespa this ratio usually fluctuates between 3.2 and 41.1 , with 16.1 as mean value during the mixing period of water, indicates that phosphorus is the limiting nutrient for algal growth

Fur thermore the concentration of dissolved phosphate has been compare with the presence of some algal taxa. The measurements indicate that there is algal activity, mainly from chlorophyceae (Elakatothrix gelatinosa Wille, Scenedesmus quadricatda Turp.em.Chod., Selenastrum gracile Reinsch,) and bacillariophyceae (Cyclotella ocellata Pant, C.meneghianiana Kutz, Nitzschia holsatica Hust, and Navicula gracilis Ehr) during spring, when the concentration of $o-P$ ranges from 4.0 to $5.2 \mu \mathrm{g} \mathrm{l}^{-1}\left(4.6 \mu \mathrm{g} \mathrm{l}^{-1}\right.$ mean value). During summer period, when the dominating groups are chlorophyceae (Closterizm gracile Bred., Selenastrum bibraiantum Reinsch, Scenedesmus quadricauda Turp.em.Chod.), bacillariophyceae (Cyclotella ocellata Pant. Melosira granulata (Ehr) Ralfs and Naricula cryptocephala Kütz) and cyano- 
phyceae (Chroococcus limneticus v. distans G.M. Smith, Aphanocapsa pulchra (Kük) Rabh, Microcystis flos-aquae (Wittr.) Kirchn., M. aeruginosa Kütz) the $\mathrm{o}-\mathrm{P}$ ranges from 8.0 to $10.5 \mu \mathrm{g} \mathrm{l}^{-1}\left(9.3 \mu \mathrm{g} \mathrm{l}^{-1}\right.$ mean value). The same values of o-P are found until late September and algal blooms remain present. Under certain meteorological conditions (high temperatures, little to no rainfall, high evaporat ion rates etc.), Lake Mikri Prespa may have such a high biomass that its decay might cause deficiency of dissolved oxygen and phosphate enrichment in the hypolimnion (Koussouris \& Satmadjis 1987).

\section{The model}

Evaluation of the trophic status can been done by several nutrient loading models (e.g. Vollenweider 1975, Dillon et al. 1974, Kirchner et al. 1975). The Dillon et al. model was used to consider the balance of total phosphorus in the Lake Mikri Prespa. The model assumes the lake to be homogenous completely mixed and at steady state. The model showed that the total nutrient concentration in surface water is directly proportional to the nutrient loading.
$\mathrm{L}(1-\mathrm{R}) \mathrm{t}=\mathrm{Z} \times \mathrm{N}$

where :

$\mathrm{L}=$ Areal nutrient loading, $\mathrm{g} \mathrm{m}^{-2} \mathrm{y}^{-1}$,

$\mathrm{R}=$ Fraction of nutrient retained in the lake

$=0.426 \mathrm{e}^{-0.27 \times s q}+0.574 \mathrm{e}^{-0.00949 \times \mathrm{qs}}$

(Kirchner \& Dillon 1975)

$$
=0.3081+0.5675=0.88\left(\mathrm{qs}=1.2 \mathrm{~m} \mathrm{y}^{-1}\right)
$$

$\mathrm{t}=$ Hydraulic retension time $(\mathrm{t}=\mathrm{V} / \mathrm{Q}=3.4$ years $)$

$Z=$ Mean depth $(Z=4.1$ meters $)$

$\mathrm{N}=$ Total nutrient concentration in lake, $\left(0.028 \mathrm{~g} \mathrm{~m}^{-3}\right.$ ( $\mathrm{mg} \mathrm{H} \mathrm{H}^{-1}$ ).

Calculated in this way, the loading of phosphorus appeared to be $0.28 \mathrm{~g} \mathrm{~m}^{-2} \mathrm{y}^{-1}$ or about $15000 \mathrm{~kg} \mathrm{y}^{-1}$ for the lake surface.

The nutrient loading into a lake can be estimated among other methods by using export coefficients given by Rast \& Lee (1983) and Tomps Corp. (1974). Phosphate enters the lake basin from many sources such as, atmospheric fallout and precipitation, runoff by land-use, septic tanks of the rural area and the excreta of livestocks and avifauna.

Based on these coefficients the Lake Mikri Prespa received a phosphorus loading of about $15.0 \times 10^{6} \mathrm{~g}^{1}$

Table IV. Estimation of phosphorus inputs in Lake Mikri Prespa according to export coefficient factors vs. land-uses and other sources (* Rast \& Lee, 1983 and $* \star$ Tomps corp., 1974).

\begin{tabular}{|c|c|c|c|c|c|}
\hline $\begin{array}{l}\text { Land-use } \\
\text { Other sources }\end{array}$ & $\begin{array}{l}\text { Area } \\
\mathrm{km}^{2}\end{array}$ & Individuals & $\underset{\text { g km² }}{\mathbf{P}_{\text {ex }}}$ & $\mathrm{F}$ & $\begin{array}{l}\mathbf{P}_{\mathrm{L}} \\
\times 10 \\
\mathrm{gy}^{-1}\end{array}$ \\
\hline Forest & 150 & - & $0.01^{*}$ & 1 & 1.5 \\
\hline $\begin{array}{l}\text { Conventional } \\
\text { Agricultural }\end{array}$ & & & & & \\
\hline $\begin{array}{l}\text { Area } \\
\text { Irrigated } \\
\text { Area }\end{array}$ & 7.4 & - & $0.08^{*}$ & 1 & 0.59 \\
\hline $\begin{array}{l}\text { Pasturing } \\
\text { Land }\end{array}$ & 37.7 & . & $0.08^{*}$ & 1 & 3.02 \\
\hline $\begin{array}{l}\text { Direct } \\
\text { Precipitation } \\
\text { on Lake }\end{array}$ & 53 & . & $0.0025^{\star}$ & 1 & 0.13 \\
\hline Population & - & 2000 & $109^{\star \star}$ & 1 & 0.22 \\
\hline $\begin{array}{c}\text { Liverstock } \\
\text { - sheeps } \\
\text { - pigs } \\
\text { - cattles }\end{array}$ & : & $\begin{array}{r}4000 \\
200 \\
500\end{array}$ & $\begin{array}{l}2500^{\star *} \\
2500^{\star *} \\
15000^{\star *}\end{array}$ & $\begin{array}{l}0.3 \\
0.1 \\
0.7\end{array}$ & $\begin{array}{l}3.0 \\
0.05 \\
5.25\end{array}$ \\
\hline Avifauna & . & 2500 & $25 \times 4^{*}$ & 1 & 0.25 \\
\hline
\end{tabular}

Key : $\mathbf{P}_{\mathrm{ex}}=$ Phosphorus export coefficient $\mathbf{F} \stackrel{\mathrm{ex}}{=}$ Factor

$\mathbf{P}_{\mathbf{L}}=$ Phosphorus loading. 


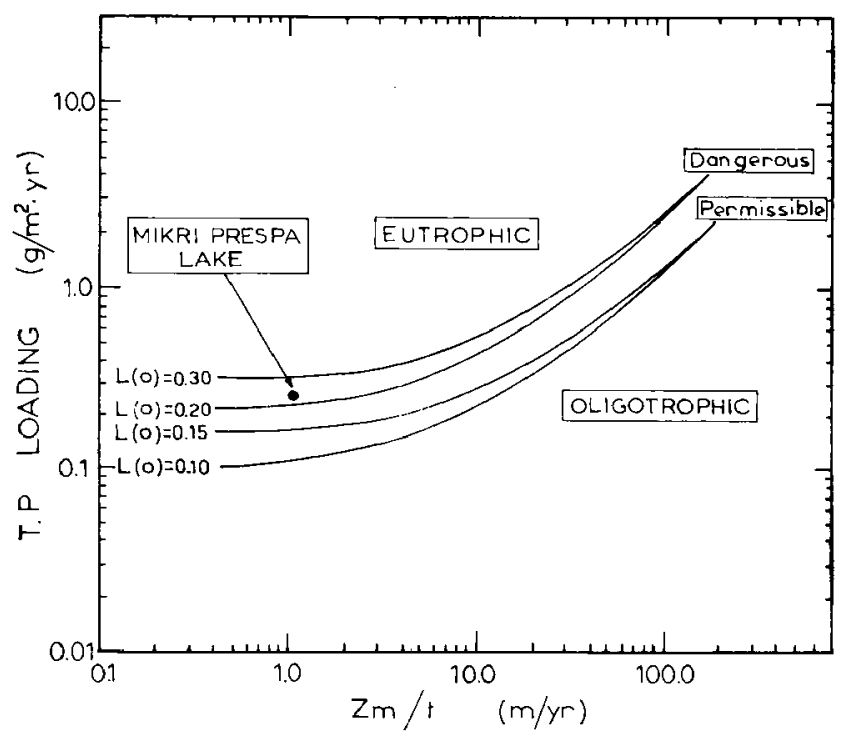

Fig. 3. The Vollenweider's relationship applied to Lake Mikri Prepa for dangerous and permissible phosphorus loading.

(see Table III). Assuming that $100 \%$ of the above loading reaches the lake, the surface loading becomes above $0.2 \mathrm{~g} \mathrm{~m}^{-2} \mathrm{y}^{-1}$.

Of the above $15000 \mathrm{~kg} \mathrm{y}^{-1}$ loading, only $2000 \mathrm{~kg}^{-1}$ will leave the system in the outflow and the rest (about $13000 \mathrm{~kg} \mathrm{y}^{-1}$ ) will sedimented.

Based on Vollenweider's (1976) critical loading relationships of phosphorus for a lake with mean depth less than five meters $\left(\mathrm{L}_{\mathrm{c}} / \mathrm{q}_{\mathrm{s}}=(10-20)(1+\mathrm{t})\right)$, the critical loading for Lake Mikri Prespa should be 0.07 $\mathrm{g} \mathrm{m}^{-2} \mathrm{y}^{-1}$ and the permissible loading $0.03 \mathrm{~g} \mathrm{~m}^{-2} \mathrm{y}^{-1}$ (Fig. 3). Consequently the lake can be classified as meso- to eutrophic (O.E.C.D.) while a loading of 0.27 $\mathrm{g} \mathrm{m}^{-2} \mathrm{y}^{-1}$ (Fig. 3) is near the dangerous level.

If however the proposed development projects of the area take place, through the intensified agricultural practice and the operation of the new hutchery, the expected enrichment of the lake water could affect the lake's ecosystem and might be devastating during drought.

\section{References}

Dillon (P.J.) \& Rigler (F.H.). 1974. - A test of a simple nutrient budget model predicting the phosphorus concentrations in lake water. J. Fish. Res. Bd. Can., 31 : 177 1-78.

I.G.M.E. 1983. - Geological map of Mikri Prespa, Sheept No 35.

Katsadorakis (G.) 1986. - Biotopes and vertebrates in Prespa National Park. Depart. of Biol. Univers. of Athens, Greece, 161 pp.

Kirchner (N.B.) \& Dillon (P.J.) 1975. - The effects of geology and land use on the export of phosphorus from watersheds. Water Res., 9(2): 135-148.

Koussouris (T.) \& Diapoulis (A.) 1983. - For the development and protection of freshwater resources in Greece. I. Lake Mikri Prespa. I.O.F.R. Spec. Public. No 6, 89 pp.

Koussouris (T.) \& Satmadjis (I.) 1987. - Changes in plankton assemblages from spring to summer in a Greek lake. Rev. Intern. d'Oceanogr. Med, 37.38 : 51.66.

Mourkides (G.), Tsikritsis (G.), Tsiour is (S.) \& Menkisoglou (U.) 1978. - The lakes of northen Greece. 1. Trophic status 1977. Scien. Amals of Univers. of Thessaloniki, Greece, $21(5)$ : 95-1 31. 
National Meteorological Service, 1965-1985. - Meteorological data report, $15 \mathrm{pp}$.

Newbold (C.) 1986. - Wetland conservation. National Concervancy Council, Northminster House, Peterborough, report 30 pp.

O.E.C.D., 1982. - Eutrophication of waters. Monitoring, assesment and control O.E.C.D., Paris, $154 \mathrm{pp}$

Papakonstantinot (A.) 1979. - Die Hydrogeologischen Verhältnisse in Raum der Ptolemais-Senke und des westlichen Vermiongebirges in Griechisch-Macedonien. Berlinger Geowis s. Abh-Berlin, 79 pp.

Pavlidis (G.) 1985. - Geobotanical study of the National Park of Lakes Prespa (N.W. Greece). Instit. of System. Botany, Univers. of Thessaloniki, Greece, $308 \mathrm{pp}$.

Pyrovetsi (M.D.), Grivelli (P.A.), Gerakis (M.A.), Karteris (M.A.), Kastro (E.P.) and Komninos (N.) 1984 - Integrated environmental study of Prespa National Park, Greece. Report to E.E.C. Commission DG/XI, $205 \mathrm{PP}$.

Rast (W.) and Lee (G.F.) 1983. - Nutrient loading estimates for lakes. J. Env. Eng. ASCE, 109 (2): 502.517.
Soulios (G.) 1978. - Nouvelles données sur la géologie et l' hydrogéologie de la région d'Arnissa-vallée et d'Edessaios (Macédoine-Grèce). Thèse Montpellier, France, $130 \mathrm{pp}$.

Terrasse (J.F.), Terrasse (M.) \& Brosselin (M.) 1969. - Avifauna d'un lac des Balkans. Mikri Prespa, Greece. L'ois. et R.F.O, 39 : 185-20t.

Tomps Corp. 1974. - Analysis of non point pollution in the south Platte river basin. The Colorado Dep. of Public Health, report, $54 \mathrm{pp}$.

Vollenweider (R.A.) 1975. - Input-output models with special reference to the phosphorus loading concept in limmology. Schweitz. Zeitsch. für Hydrol., 37 : 53-84.

Vollenweider (R.A.) 1976. - Advances in defining critical loading levels for phosphorus in lake eutrophication. Mem. Ist. Ital. Idrobiol., $3: 53-83$.

Ward (R) 1975. - Principles of Hydrology. Mc Graw Hill Book Co., U.K, London, $367 \mathrm{pp}$.

Wetzel (R.G.) 1983. - Limnology. CB Saunders Coll. Pub. N.Y., $156 \mathrm{pp}$. 